https://doi.org/10.18485/poet_srp_real.2018.ch9

Александар М. Костадиновић ${ }^{1}$

Ниш

\title{
ЕТНОГРАФСКИ АСПЕКТИ ПУТОПИСНЕ ПРОЗЕ СИМЕ МАТАВУЉА
}

У раду се разматрају модуси присуства етнографског дискурса у путописној прози Симе Матавуља, условљени сложеним сплетом разноврсних фактора: жанровских, итеролошких, политичких... Осим „етнографског импулса”, тј. спонтаног етнографизма, какав је уобичајен за путописни жанр уопште, посебна пажња посвећена је лиминалним случајевима: 1) редукцији етнографског дискурса у путописној приповеци и 2) његовом развијању у систематичну етнографску дескрипцију.

Кључне речи: етнографски дискурс, путопис, наративна етнографија, путописна приповетка, етнографски импулс

Бављење међусобним дотицајима и прожимањима етнографског дискурса и литературе, с обзиром на релативно касно конституисање етнологије као науке, нема ону традицијску заснованост попут промишљања релација између књижевности и историографије, али представља значајно питање које све чешће заокупља пажњу истраживача̂.

${ }^{1}$ aca.kostadinovic@hotmail.com 
У домаћем књижевном зналству систематичан приступ овом проблему спроведен је у студији Драгане Вукићевић Писмо и йрича (2006), где се одношење етнологије и књижевности третира као дијалог два комплементарна семиотичка система, а разматра првенствено на корпусу српске реалистичке приповетке. Таква истраживачка оријентација има своје утемељење у следећим чињеницама: 1) друга половина XIX века представља доба експанзије етнолошких проучавања у свету и код нас; 2) народни живот у Србији оног доба кретао се још увек у границама патријархалне културе, па су и основне претензије реалистичке поетике („опонашање” савремене друштвене стварности) дошле у сагласје с етнолошким преокупацијама (проучавање културе „архаичних” друштава). Дате околности узроковале су и појаву жанровски неиздиференцираних текстова, који су „опстојавали [...] на граници између уметничке форме приповетке и етнографских записа, [тј.] прича о животу и обичајима" (Вукићевић 2007: 120). Реч је, у ствари, о „двовалентним текстовима” који су се показали као важни не само у књижевном него и у етнолошком пољу.

Наше проучавање на трагу је поменутог приступа. Бавићемо се такође списима релевантним како литерарно тако и етнолошки (мада се неретко из обе области чују и сасвим супротна мишљења), с тим што ће овога пута предмет истраживања бити путописи, за које сматрамо

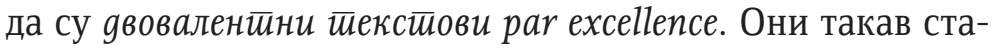
тус заслужују тиме што интерференција књижевности и етнологије у случају овог жанра превазилази афинитете одређеног доба и границе једне националне културе. Иако је путопис познат по неспутаном укрштању с другим жанровима и различитим врстама писања, однос овог жанра према етнологији посебан је по својој природи и сложе- 
ности, због чега се „етнографичност” и сматра важним (учесталим и истакнутим) обележјем путописног жанра. ${ }^{2}$

Поменута двовалентност путописа највидније се испољила током рецепције ових написа, јер су за њих карактеристична тзв. „двосмерна читања” и колебљива вредновања, ${ }^{3}$ баш као и неодлучна/противречна генолошка

\footnotetext{
${ }^{2}$ Бројни су проучаваоци путописа који управо „етнографичност" истичу као једну од важних карактеристика овог жанра. На пример, Жоан-Пау Рубијес „оригиналну етнографску информацију и имплицитне етнолошке рефлексије” [„original ethnographic information and implicite thnological reflections"] сагледава као заједнички именитељ бројних и разноврсних текстова обухваћених заједничким именитељем „путничке књижевности” [„travel literature"] (Рубијес 2000: 6, 23), указујући на чињеницу да су „описи народа̂, њихове природе, обичаја, религије, облика̂ власти и језика у толикој мери заступљени у путничкој књижевности, каква се пише на европском тлу након XVI века, да се може изнети претпоставка да је етнографија од суштинске важности за овај жанр." (Rubiés 2002: 242) - На сличне моменте упозорава и Мери Бејн Кембел, одређујући путопис као жанр „културног превођења" [„,a genre of cultural translation”] (Кембел 1988: 11), што је концепт од кључног значаја за савремену етнолошку мисао.

${ }^{3}$ Поводом рецепције „двовалентних текстова” Д. Вукићевић бележи следеће: „Јанусовска природа књижевних текстова која је пружала могућност њиховог 'двосмерног читања' није остала незапажена. Полазећи од истог текста а трагајући за различитим чињеницама (естетским или научним), и књижевни проучаваоци и етнолози врло рано су дошли до сличних закључака - „фиктивни”, прецизније, 'књижевни етнографизми' за етнологе су постали премало етнолошки (научно релевантни) а за књижевне проучаваоце премало књижевни." (2007: 206) - Неопредељеност евалуативног становишта још је приметнија приликом процењивања сазнајне/ естетске вредности путописа, тачније, у „репутацијама” које је овај жанр стекао унутар научног и уметничког поља (в. Томсон 2011: 32; Костадиновић 2016а). Изгледа ипак да је реч о феномену начелнијег важења - о трајној вредносној контроверзи која прати безмало све књижевно-документарне врсте.
} 
разврставања. Када је реч о рецепцији путописа, посебно је занимљив статус који овај жанр има у оквиру етнологије као науке.

Етнолози су често путописима приступали као извору релевантних информација, али су овај жанр ипак третирали као „параетнологију” (Поарије 1999: 21-22) или „параетнографију" (Clifford 1988: 24).Заједнички префикс у наведеним терминолошким сложеницама, који упућује на „промашај”, „погрешку”, „заблуду”, „прекорачење”, „премашај" - недвосмислено указује на то какав се статус додељује путописним текстовима у оквиру етнолошког поља. И као што се парапсихологија са становишта психологије детерминише као преднаучни/ненаучни феномен (слично као параестетика у односу на естетику), тако се и путопис из перспективе етнологије одређује као жанр који поседује сасвим „аматерски или дилетантски аспект” [„resolutely amateur or dilletante aspect”] (Thompson 2011: 32). Овај аксиолошки однос према путопису има и своје практичне консеквенце у тзв. „радњама сцијентизације” (Костадиновић 2016а: 26), помоћу којих се обезбеђују објективност, веродостојност и доследност као битне претпоставке етнографског дискурса, али и научног знања уопште. Наиме, етнолошки списи данас подразумевају одсуство „непречишћених искустава” као што су „утисци, тренутна размишљања, успутни сусрети и разговори". Све су то пратећи, према вићењу Мирослава Нишкановића, „путописни чиниоци” етнолошког истраживања, повремено уочљиви на маргинама етнолошких студија (у уводним поглављима и проширеним напоменама), али најчешће сачувани у „теренским дневницима, подсетницима, фишама", дакле, одстрањени из основног научног текста (Нишкановић 2001: 239). Међутим, ни доследан ауторски отклон од анегдотичности и поменутих субјективних форми излагања, какве су својствене путопису, није увек 
гарант јасног разликовања етнографских радова од путописних текстова.

Проблематичност и тешка остваривост једног таквог теоријског и аналитичког настојања може се илустровати написима аутора̂ епохе реализма, код којих је већ запажена тенденција да се путописи „сцијентизују [и] стручно оријентишу" (Иванић 1996: 129).

Као добро огледно подручје послужиће опус Симе Матавуља (1852-1908), јер је овај писац у више наврата и на различите начине испољавао етнографске склоности. Најпре, његова фикционална дела, нарочито она с почетка књижевног стварања, била су врло засићена етнографизмима, услед чега је критика негодовала да су му ране приповетке попут „етнографског документа” или „репортаже о обичајима", те да му је романескни првенац налик „историјско-етнографској студији”, а да је са̂м писац „више етнолог и репортер, [...] но романсијер” (Кашанин 2004: 134-135). Поврх тога, Матавуљ је написао десетак фактографски оријентисаних написа̂, с мање или више истакнутом етнолошком компонентом, који су у књижевној критици и историји углавном били детерминисани као путописи. Беспоговорна сагласност око припадности путописном жанру успостављена је за текстове Усйомене са Скаgарскої језера (1890), Ривијера (1903), Врайа

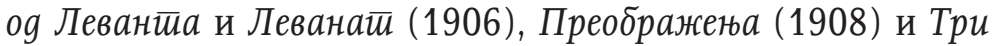
неgељь йо мору (1908). Иако такав консензус изостаје код преосталих текстова, у Матавуљеве путописе убрајају се још и састави „'на међашу' између причице и путописа"4

${ }^{4}$ Овако на хибридну природу датих текстова упућује Голуб Добрашиновић, уредник Сабраних gела Симе Матиавуља из 20072008, сматрајући ипак да они својом „основном концепцијом [јесу] блискији приповједачком жанру" (Добрашиновић 2007: 465), због чега их је - за разлику од ранијих редактора̂ и тумача̂ - разместио у књиге приповедака̂. 


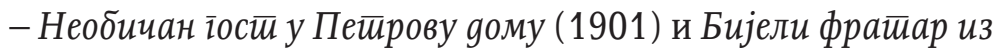
Дубровника (1908); затим дневничке белешке с путовања̂ у Далмацију $(1901,1902)$, за Беч (1902) и Ницу (1903); ${ }^{5}$ као и напис Бока и Бокељи (1893) који је од посебног значаја за проблем који нас овде занима. ${ }^{6}$

Наиме, последњи од наведених списа својим предметом, композицијом и другим реторичким поступцима одговара готово свим очекивањима која се испостављају пред научну студију етнографске или антропогеографске садржине. Текст је подељен у пет поглавља у којима аутор редом разматра: 1) географски положај и демографске карактеристике Бокељског залива; 2) историјску прошлост, легенде и предања локалног становништва; 3) социјалну структуру; 4) поморство као главну привредну грану; 5) климатске одлике поднебља, етнопсихолошке карактеристике живља и др. Осим тога, у тексту је остварена мак-

\footnotetext{
${ }^{5}$ Матавуљеве дневничке белешке, писане без икакве намере да буду објављене, представљају, у ствари, хронолошки организован трошковник путовања и могле су аутору евентуално да послуже као подсетник при обликовању путописаิ. Иако није реч о „правим" путописним текстовима, ови записи припадају сфери „putničke proizvođačke prakse”, чије познавање може бити важно за разумевање путописних жанровских погодби (Дуда 2005: 100; Костадиновић 2016а: 22-24).

${ }^{6}$ Жанровско одређење Матавуљеве књиге о Боки као „путописног текста у форми објективне научне студије" понудио је Горан Максимовић (2007: 136), заступајући једну прилично инклузивну концепцију путописног жанра. Из тог разлога његов је преглед Матавуљевих путописних дела обухватнији од оних које су понудили претходници: Драгиша Живковић, Станко Кораћ, Г. Добрашиновић и др. (Максимовић 2010: 77-78). Овакво разумевање путописа, као комплексног генолошког појма који обухвата текстове различитих циљева и конвенција, сасвим је у складу с актуелним поимањем овог жанра, али и с општим епистемолошким тенденцијама у савременој генологији (в. Костадиновић 2016б).
} 
симална мера строгости и објективности излагања, што је учинак реторичких процедура као што су: 1) ауторско упућивање на постојећи корпус знања/литературе о датом предмету, ${ }^{7}$ 2) редуковање персоналних „ја-исказа” (који су препознатљива одлика путописног жанра), 3) прецизно бележење квантитативних односа (поступак енумерације), и сл. Напокон, и околности које се тичу генезе и публиковања овог текста упућују на његов научни или, макар, научно-популарни карактер: по свом пресељену у Београд аутор је најпре одржао јавно предавање „Из живота и обичаја наших јужних примораца" (1890), на чијим основама ће накнадно израдити рукопис и објавити га у Матици српској - у едицији „Књиге за народ”, познатој по свом просветитељском, поучно-забавном усмерењу.

Упркос свим побројаним одликама, овом Матавуљевом напису није приписиван искључиво научни карактер. Готово сви тумачи Матавуљевог дела придавали су овом тексту и путописну димензију, што се да регистровати већ по употребљеним жанровским индикацијама: Бока и Бокељи именовани су једноставно као „путопис”, као „више етнографски него [ли] путописни спис”, као „етнографско-путописна студија"... (Живковић 1954: 593; Кораћ 1982: 309; Максимовић 2007: 136) Најзад, подстицај овим генолошким недоумицама дао је и са̂м Матавуљ, различитим жанровским „самоименовањима”. У писму Милану Савићу (30. маја 1891) писац своје дело одређује као „једну етнографску радњу о Боци” (Матавуљ 2009: 198),

\footnotetext{
${ }^{7}$ Већ у уводним реченицама Матавуљ помиње Стефана Митрова Љубишу као свог непосредног претходника на задатку описивања Боке (Љубишин путопис Бока), а затим подсећа и на сродне текстове других бокељских „домородаца” (Л. Томановића, Ј. Јелчића, Т. К. Поповића, Баловића). Аутор упућује још и на Караџићеве и Врчевићеве етнографске списе, те на путописне радове Љубомира Ненадовића и Милана Јовановића Морског. (Матавуљ 2008: 284, 291)
} 
не би ли у самом тексту „етнографске радње”, у једном аутопоетичком коментару, употребио жанровску индикацију - „путни вођ за извањце”.

Као што смо већ истакли, наведено терминолошко и концептуално колебање не представља куриозитет који се тиче само путописног и етнографског стваралаштва овог аутора, ${ }^{8}$ нити се среће искључиво у нашој књижевности. Напротив, поновљивост и учесталост такве ситуације наметнула је питање да ли између етнографије као научне области и дискурсне праксе, с једне стране, и путописа

${ }^{8}$ Као још један пример сличних потешкоћа може се узети рецепција и вредновање путописно-етнографских списа Бранислава Нушића. Нушић је аутор три таква текста: 1) Крај обала Охрияскоіа језера: белешке из 1892. іодине (1894), 2) С Косова на сине море: белешке с йуйа кроз Арбанасе 1894. іоgине (1902), и 3) Косово: ойис земље и нароga (1902). Историчари књижевности овим написима нису негирали само уметничке претензије, већ је њиховим судовима имплицитно (жанровском десигнацијом) изражена и скепса поводом пуне научне валидности датих радова: они су сврставани у путописну и мемоарску прозу, упркос јасним (пара)текстуалним сигналима да су, макар неки од њих, писани и са нешто друкчијим, научним претензијама (Скерлић 1997: 364; Деретић 2007: 980). - Пријем и историјско деловање Нушићеве двотомне монографије Косово: ойис земље и нароgа у многоме подсећа на рецепцију Матавуљеве студије Бока и Бокељи. У стручној (етнолошкој) литератури она је прихваћена као књига чији су увиди потврђени доцнијим научним истраживањима. Међутим, без обзира на солидне научне заснове и резултате ове Нушићеве књиге, она се у етнолошким круговима наизменично, а изгледа и арбитрарно, одређивала као путописни и/или етнографски напис. Извесну терминолошку несигурност и двосмисленост садржи чак и изразито похвални суд Петра Влаховића гледе научне заснованости Нушићевих списа̂: „Свако његово йуйойисно gело, а посебно 'Косово, опис земље и народа', несумњиво је обрађено йо свим науиним йриниииима који су се у то време примењивали у друштвеним и културно-историјским наукама." (1986: 308. Курзив А. К.) 
као књижевно-документарне врсте, с друге, може бити повучена јасна граница. Чини се да то није сасвим изводљиво, макар не у мање јасним жанровским случајевима, какви су реализовани у оквиру тзв.„научног/ученог модуса путописања" [„,scholarly mode of travel writing”] (Томсон 2011: 93). У поменутом модусу појачана етнографичност не подразумева само учесталост етнодескрипција и информативног коментара етнографске садржине, већ и сцијентизацију целокупног путописног излагања, што је поетичко и епистемолошко стремљење карактеристично за читаво XIX столеће у Европи. ${ }^{9}$

Основне одлике научног путописања тичу се како текстуалног уобличења путничког искуства, тако и непосредног организовања путничке праксе. Задржи ли се пажња само на текстуалним аспектима овог процеса, уочиће се читав низ обележја сцијентистичког дискурса као „епистемолошког декорума” [„epistemological decorum”] особеног за научни или академски путопис, ${ }^{10}$ која смо већ иденти-

${ }^{9}$ Најпре, то је век империјалне експанзије водећих европских сила, доба успостављања пуне прекоморске хегемоније; што за своје последице има и нагли развој хуманистичких (антрополошких) дисциплина, њихову пуну диференцијацију и специјализацију, и, на самом крају тог процеса, научну кодификацију путописне праксе.

${ }^{10}$ Појам „епистемолошког декорума” увео је историчар Стивен Шапин [Steven Shapin], а на путописну област почиње да га примењује К. Томпсон. С обзиром на то да путописи обично прокламују „жанровску усмереност на истину”, а да су до краја XIX века били третирани првенствено као дидактички написи чија је основна сврха трансмисија информација, сасвим је природно да се за овај жанр формирао специфичан епистемолошки декорум који је требало да сугерише тачност изнесених података. У питању je, заправо, дијахронијски варијабилан скуп путописних погодби које сугеришу веродостојност и плаузибилност, а К. Томпсон разликује три основна типа путописног епистемолошког декорума: 1) 
фиковали у Матавуљевом напису о Боки. У таква обележја спадају: 1) појмовни (категоријални) систем специфичан за одређену научну област (што се обично манифестује у насловима поглавља), 2) минимално учешће персоналног наратива, 3) упоређивање личних открића и путничких запажања с корпусом знања оствареним у датој науци (позивање на стручну литературу), 4) тенденцију за квантификовањем и пружањем мерљивих резултата, што се манифестује у помињаном поступку енумерације, 5) разна пратећа (формална) обележја „научности”, тј. прецизности излагања (употреба цитата и фуснота). итд. Све наведене карактеристике могуће је уочити не само у Матавуљевом „путном вођу” и/или „етнографкој радњи” Бока и Бокељи, већ и у сличним написима бројних других аутора: Павла Шица, капетана Михаила Илића, Матије Бана, др Анте Гвозденовића, Б. Нушића... Сцијентистички декорум заступљен је код свих поменутих, а имао је за циљ да путописни састав пружи објективну и поуздану, дакле, научну (или налик на научну) информацију. ${ }^{11}$

„средњовековни декорум” који идеју веродостојности заснива на усклађености путописа с канонским делима и писцима (светим оцима, филозофима, географима), 2) „декорум наивног емирицизма" који ваљаност информација подупире ауторитетом сведочења, тј. лично проживљеног искуства („персоналним наративом” и „дневничким белешкама"), 3) и „сцијентистички декорум" који објективност информације предочава поштовањем процедура научног дискурса (в. Томпсон 2011: 72-84).

${ }^{11}$ Врхунац описане сцијентистичке тенденције свакако представља онај моменат када географија, социологија, антропологија (етнологија) - као науке у великој мери повезане с путописном праксом, па и генерисане из те праксе - досежу пуну диференцијацију, осамостаљивање и специјализацију. На тој тачки представници поменутих наука заузимају крајње ригористички однос спрам сопственог преднаучног порекла, одстрањујући из својих редова истраживаче-аматере - „обичне путнике" [„meretravelers"] и „Уз- 
Посебан проблем при разграничавању путописа и етнографије представља чињеница (на којој се овде не можемо опширније задржати) да су ове две списатељске праксе дијахронијски имале међусобно променљив однос, те да су се и саме значајно мењале у времену. Већ је поменуто да је путничка књижевност била место рађања емпиријски оријентисаног научног дискурса, па и самих етнодескрипција. Такву „спонтану етнографичност” (или макар ону која није сасвим строго уређена), каква претходи деветнаестовековном конституисању „академског дискурса заснованог на компарацији, класификацији и историјском пореклу" који данас препознајемо као етнологију, Жоан-Пау Рубијес назива „етнографским импулсом" (2002: 243). ${ }^{12}$ Осим тога, путописна проза није

гредне посматраче” [„casual observers”]. Наравно, оваква аутолегитимизација остварује се по цену критичке самосвести: „У мери у којој себе легитимизује опонирањем у односу на друге врсте писања, етнографија чини себе слепом за чињеницу да су њене сопствене дискурсне процедуре често наслеђене од тих других жанрова, те да их и сама још увек дели са њима." (Прат 1986: 27) - Очигледно, процењивање научног/академског путописа као „параетнографије” не полази само од устројства текста (вербални, синтаткички и семантички аспект дискурса), већ и од низа пратећих околности, које такође утичу на његову стручну легитимизацију. На пример, основни проблем код Нушићевих етнографских списа је био тај што се писцу није могао доделити статус „истраживача” као „добро обученог професионалца" ["highly trained professionals"], а то је био један од основних етнолошких критеријума (Томсон 2011: 81). Осим тога што је својим образовањем Нушић представљао „истраживача-аматера”, извесну сметњу за адекватну рецепцију његових списа могла би да представља и чињеница да је књижевну славу стекао као „хумориста и комедиограф”, али и његов незванични статус литерарног „брзописца" (в. Влаховић 1986: 308; Ђурчинов 2001: 446).

${ }^{12}$ Мери Бејн Кембел овакве елементе у раној путописној књижевности назива „протоетнографским квалитетима” (в. Борм 2000: 80-81). 
само место генезе спонтаних етнографских тенденција, већ управо ту отпочињу и процеси сцијентизације, тј. методолошке организације и систематизације етнолошког знања. На пример, познат је феномен тзв. „етнолошких упитника" који су представљали својеврстан етнографски водич у правилном прикупљању и организовању података с терена. ${ }^{13}$ На нашем простору таква су, рецимо, Цвијићева упутства о антропогеографским проучавањима из 1896. године. У свету, према мишљењу Жана Поаријеа, један од првих „anketnih vodiča u etnologiji” састављен је век раније 1799. године под насловом „Razmatranja o različitim metodima koja valja slediti u posmatranju divljih naroda". За нас је од посебног значаја то што је овај спис, усвојен као званични документ на седници „Друштва посматрача човека", био састављен поводом истраживачке мисије капетана Бодена у аутралијским земљама (1800-1804). Ово француско друштво „филозофа” (а, заправо, лекара, природњака, историчара, правника...) je као свој важан задатак истакло упућивање мисија̂ у егзотична друштва и „podržavanje projekata putopisaca”, а та се подршка, између осталог, састојала и у обликовању упутстава „која ocrtavaju program jedne celovite etnografske ankete" (Поарије 1999: 21-22). Међутим, и један и други датум припадају већ прилично позном стадијуму кодификације етнографске праксе, пошто се још током позног XVI в. у оквиру путничке књижевности појављују прве „инструкције” и „методи” за путнике, као путнички поджанр који садржи скуп препорука у вези с тим како да се на методичан начин прибележи оно што је

${ }^{13}$ Нушићева монографија Косово: ойис земље и нароgа задовољила је и овај критеријум научности, јер је емпиријска грађа у њој била „сабрана по упутствима за прибирање теренске грађе која су [аутору] дали Стојан Новаковић и Љуба Ковачевић, редовни чланови Српске краљевске академије" (Влаховић 1986: 301-302). 
на путу виђено (Рубијес 2002: 253). То, у ствари, значи да је научна или, тачније, преднаучна систематичност битна одлика одређеног броја путописа, те да се она преносила као конвенција путописног жанра све до издвајања и конституисања етнологије као засебне науке.

Судећи по свему, етнографију и путопис треба посматрати као два жанра или, барем, као „две форме писања” које се „додирују и преклапају на бројне начине, али су и јасно одвојене на основу преовлађујућих чинилаца". Као заговорник таквог, флексибилнијег поимања жанровских категорија, Јан Борм сматра да се ове две списатељске праксе, упркос многим заједничким особинама, разликују на основу „доминације одређених елемената или скупова компонената над другима" (Борм 2000: 78, 92): стога, иако се путопис прилично често бави етнолошким питањима, то га још увек не изједначава с етнографијом у строгом значењу тог термина; као што се ни модерна етнографија (која често користи миметичке поступке, те инкорпорира многе путописне елементе) не може идентификовати као путописање. Наиме, није оправдано очекивати да путопис буде доминантно дискурзиван и научан у свом методу презентовања етнографских чињеница, нити треба очекивати да ће персонални извештаји о путовању доминирати етнолошком монографијом. За нас је посебно занимљиво да Борм уочава и постојање таквих текстова чија је двовалентност јако изражена, због чега се они у жанровском смислу морају сместити „негде између”. ${ }^{14}$

14 За означавање скупине оваквих текстова Борм се послужио термином „наративна етнографија” Жака Мунијеа [Jacques Meunier]. Иако савремена генологија не пориче постојање оваквих, жанровски неопредељених текстова (в. Костадиновић 2016б), употребљена жанровска одредница чини се проблематичном јер не мора само наративност бити фактор који одређени напис пози- 
Ако после свега изреченог размотримо одлике Матавуљевог текста Бока и Бокељи, чини се сасвим оправданим посматрати га као дело с научним, етнографским и антропогеографским претензијама, чија је структура одређена доминацијом сазнајне функције и вредности, с тим да се његова евентуална припадност путописном жанру мора нешто подробније прокоментарисати. Најпре, композициони поступак којим се Матавуљ служи у уводном поглављу свог списа („Опис Боке. - Знатније повесничке напомене и статистички подаци") карактеристичан је управо за неке видове путописне прозе. Реч је о вирйуелним йуйовањима, где се синтакса текста организује око хипотетичког (уобичајеног) итинерара и редоследа путних дестинација: за таквим решењем посезали су најчешће они аутори који нису приповедали о појединачном и конкретном путничком искуству, већ су настојали да једним синтетичким излагањем „покрију” своја вишеструка путовања до одређене дестинације. У таквим путописним текстовима нагласак је на оном регуларном и хабитуалном, па тако и Матавуљ настоји „да се читалац проведе кроза [Боку] како је најзгодније, [...] улазећи у њу како и море улази" (Матавуљ 2008: 284), тј. да се представи Бока оним редоследом којим се указује путнику када парном лађом крене од Дубровника. ${ }^{15}$ Друго, иако естетска функција и

ционира у гранично подручје између књижевности (путописања, у модерном смислу те речи) и науке (етнологије).

15 У свим написима сличне концепције на делу је биторовска трочлана метафора која успоставља једнакост између чинова писања, читања и путовања, па се писац и читалац овде идентификују с путником. Тако, на пример, Милан Јовановић Морски у књизи Тамо амо йо Истиоку (1894) позива своје читаоце „у памети да пропутуј[у] заједно по том големом Истоку". Да је реч о путовању као специфичном композиционом поступку којим се организује информативни дискурс најбоље показује случај тзв. „имагинарних 
вредност иду у ред новијих читалачких очекивања (редовно испостављаних пред путопис тек у XX веку) ваља указати и на оне аспекте Матавуљевог текста у којима се да̂ наслутити „мајстор приповедач”. У критици је, углавном, усаглашен став да четврто поглавље студије, посвећено развоју и пропасти бокељског поморства, завређује посебну пажњу јер је „занимљиво и више изворно” од осталих (Добрашиновић 2007: 526), те да ту долази „до изражаја и [ауторов] врсни приповједачки дар: упечаљтив језик, изузетна моћ посматрања и уочавања особених детаља, цјеловити портрети [...] и слично." (Максимовић 2007: 145) Чини се да је Матавуљ управо у овом поглављу свог текста био најближи ономе што Ј. Борм назива „наративном етнографијом". Међутим, осим истицања формалних, синтаксичких и семантичких карактеристика разматраног поглавља, потребно је опоменути и на важност прагматичких аспеката - на то да „функционисање текстова (било којег текста) зависи од начина на који су они читани" (Борм 2000: 91). Наиме, није могуће сасвим поуздано утврдити да ли уметничке вредности датог поглавља уистину прекорачују праг „стилске нијансе”, што је Етјен Рабате сматрао крајњим дометом путописања (в. Борм 2013: 612-613), или је, пак, реч о густој интертекстуалној мрежи на основу које читалац појачано доживљава естетску резонанцу текста. ${ }^{16}$ Укратко, није јасно да ли овде препознајемо елементе белетристичког приступа материји

путописа" Милутина Миланковића, где истинског путовања нема јер се „путује”, како то са̂м писац вели, кроз „бесконачност васионе" и „сретнија времена прошлости".

${ }^{16}$ Осим експлицитних упућивања на текстове Петра Петровића Његоша и Милана Јовановића Морског, упућенији читалац на овом месту ће лако уочити интертекстуалне везе с познијим приповедним и путописним остварењима С. Матавуља: Први Божић на мору (1899) и Преображења (1907). 
првенствено зато што смо навикнути да Матавуља читамо као писца „лепе књижевности".

Очигледно је, дакле, да етнографичност путописа представља скаларну карактеристику која се може испољавати у различитим степенима, ${ }^{17}$ па и у разноврсним модусима: с обзиром на све досад изречено, поновни поглед на Матавуљев путописни опус уочиће сасвим различит статус етнографских чинилаца у зависности од морфологије текста, тј. од (под)жанровске припадности истог. У оним Матавуљевим написима који задовољавају стандардне представе о путописном жанру, а то су: Усйо-

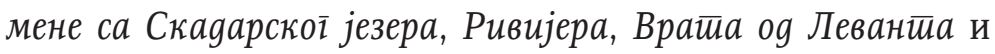

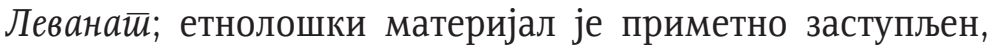
али је очигледно подређен персоналном приповедању о самом току путничког подухвата. ${ }^{18}$ Сасвим је друга ситуа-

17 Рубијес, иако заговорник идеје о суштинској вези између етнографије и путописања, износи и следеће запажање: „Путничка књижевност, разноврстан корпус текстова, који за есенцијални услов своје производње има путовање, појављује се у много облика које је најбоље дефинисати у њиховој мноштвености. Етнографија је од средишњег значаја за одређене облике, сасвим споредна за друге, а понекад је сасвим одсутна." (2002: 244)

${ }^{18}$ Према мишљењу Мери Луиз Прат, смењивање „персоналног наратива и објектификоване дескрипције" јесте једна од најважнијих погодби путописног жанра, јер је већ током XVI века постало конвенционално да се путописи састоје „из комбинације приповедања у првом лицу, чији је предмет путовање, и дескрипције флоре и фауне похођених регија, те описа нарави и обичаја [локалног] становништва". Још онда је успостављен и мање-више трајан и стабилан путописни поредак између приповедања и описивања, где дескрипција има другоразредни значај (Прат 1986: 33, 35). Иначе, чини се да Пратова термином „објектификована дескрипција" обухвата све видова пауза у путописном приповедању, због чега у етнодескрипције укључује и „етнографске генерализације” [„ethnographic generalizations"] и коментар [„commentary"]. 
ција у мање обичним, лиминалним случајевима, тамо где путописање значајније интерферира с другим жанровима и дискурсним праксама, јер се учешће етнографских чинилаца креће у распону од структурне доминације до њиховог потпуног редуковања. Видели смо, код научног/ академског путописа етнографичност не само да узима количински примат, већ и целокупно путописно излагање прилагођава научним претензијама.

Што се, пак, тиче Матавуљевих путописних приповедака, у њима је до пуног изражаја дошла „умјетничка тежња да [се] путопис претвори у причу", тј. да се заснује као „занимљиво казивање о догађајима и људима” (Максимовић 2010: 106). Преусмеравање путничке пажње са похођеног простора на акцију и актере, као и премештање ауторских преокупација са сазнајних на естетске аспекте путописног излагања не резултује само појачаном заступљеношћу тзв. „фикционалних” поступака и конвенција (в. Борм 2013: 609, 618), већ за своју последицу има и то да обимни информативни пасажи етнографске, географске, социолошке и историографске садржине, сасвим уобичајени за путописну прозу XIX века, овде буду сведени на најмању могућу меру или чак сасвим редуковани. ${ }^{19}$ У Бијелом фрат̄ру из Дубровника поменути структурни

${ }^{19}$ Оваква редукција информативног дискурса карактеристична је и за „путничке новеле” М. Јовановића Морског, окупљене у књизи C мора и са сува (1892). Матавуљ је, уз поменутог аутора и Владана Ђорђевића, трећи српски књижевник који се окушао у путописној причи, као ретком и мало запаженом путописном поджанру у српској књижевности XIX века. Ако се изузме разумљива и очекивана супституција романтичарских одлика онима из реалистичког проседеа, Матавуљ се може сматрати настављачем путописног и приповедног модела који је обликовао Морски, јер су наративи те врсте код обојице изграђени на издвојеној путничкој епизоди и хронотопу сусрета, те на модификовању аутодијегетичког приповедног режима (уобичајеног за путопис) у хомодијеге- 
чинилац трансформисан је у каталог знаменитих личности из културне прошлости града, док је у Преображењима претворен у кратку опаску из домена економије. ${ }^{20}$

Посебно је занимљив случај приче Необичан іости у Пейрову gому, где Матавуљ извештава о свом боравку у Риму 1900. године, конкретно о посети Катедрали Светог Петра. Наиме, путописац овде не предузима исцрпно фактографско извештавање о монументалној римској грађевинини, какво би било уобичајено за путописну прозу, већ се усредсређује на случајни сусрет са суботичким Буњевцима. Речено одступање од стандардних путописних процедура образложено је тиме што такви написи о овом споменику представљају опште место (српске) путничке књижевности:

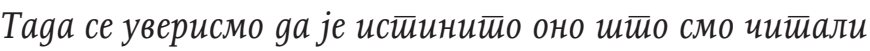
u og gруі̄uх иули, то је да не толико очи, на први мах, колико ноге показују необичне сразмере огромне зграде, јер од уласка до те светиње дужина је стотину и тридесет и пет метара. Гробница је велика јама, опкољена ступчићима и коломатом од драгоцена мрамора, на коме дан и ноћ гори осамдесет и седам позлаћених великих кандила. Доле се силази низ мраморне степенице, које изводе пред златне двери, за којима почивају моћи светог апостола. Над том светињом, у висини од сто педесет и три метара, лебди чувено и прекочувено Микеланђелово кубе, одакле се разлива сунчева светлост. Од гробнице до црквеног краја, до великог олтара, пређосмо још педесет и један метар, јер је дужина црвке стотину

тички, где драматизовани приповедач има превасходно улогу посматрача и сведока.

20 Преображења представљају текст који се обично сврстава у ред „стандардних” Матавуљевих путописа. Међутим, по својим структурним одликама он се нимало не разликује од осталих путописних прича овог аутора. 
и осамдесет и пет и по метара. Вратисмо се јужним разделом, па се поново упутисмо ка главном олтару, северном страном.

Није ми намера gа оиисујем йу највећу и најлейшу иркву у хришћанствв; имамо више оииса юених и у нашем језику, а иначе налазе се у сваком Вођу (Guide). Нас двоје свраћасмо по неколико минута у седам њених капела, застајасмо испред тридесет њеких олтара, четрнаест раскошних гробних споменика и небројених стубова, кипова, разних украса, итд., па нам у томе протекоше пуна четири сата као четири тренутка.

(Матавуљ 2007: 255-256. Курзив А. К.)

Поред тога што садржи коментар који се тиче интенционалног аспекта текста, цитирани одломак пружа увид у још једну његову важну одлику. Поступак енумерације, који овде осим поузданог бележења трајања̂ у времену („по неколико минута”, „пуна четири сата”) и протезања̂ у простору (дужина од „стотину и тридесет и пет метара”, „висина од сто педесет и три метара", растојање од „педесет и један метар"...) обухвата и тачно набрајање материјалних датости („осамдесет и седам позлаћених великих кандила”, „тридесет њеких олтара”, „четрнаест раскошних гробних споменика"), представља чинилац који путописну прозу уопште повезује с научним дискурсом и, најчешће, има функцију показатеља путописне тежње за егзактношћу. Међутим, у тексту који не претендује на то да пружи минуциозан али ни нов опис одређеног локалитета, појава енумерације има сасвим другачију реторичку функцију: вишеструко набрајање треба да нагласи првенствено један моменат - да је Катедрала Светог Петра у Риму „највећа и најлепша црква у хришћанству"! То значи да је енумерација овде укључена у реторички поступак „надмашивања” („Überbietung”), где се нека личност или ствар хвали тако што се „доказује да [...] она надмашује све слично”, што је 
саставни део „панегиричког стила” (Курцијус 1996: 261262, 269-272), односно „хиперболичког стилског комплекса" (Живковић 1994: 216-218). ${ }^{21}$ Дакле, оно што је поступак који обично сугерише прецизност, премда ту сугестију никада не треба примати без резерве, овде функционише као реторички еквивалент хиперболи.

На крају, требало би размотрити још једно важно питање - евентуалну зависност између тзв. „путописне географије", специфичне просторне оријентације конкретног путописног састава и заступљености етнографских чинилаца у њему. На овом степену проучености грађе, у вези с тим проблемом могуће је изнети тек пар претпоставки. Евидентна је чињеница да су етнографски импулси заступљенији у Матавуљевим списима са домаћег тла него ли у путничким извештајима из страних земаља: не само да је спис Бока и Бокељи обликован на форму етнографске студије, већ је и Матавуљев путописни првенац Усйомене са Скаgарскоі језера (1890), густо премрежен етнолошком проблематиком (фонетске и лексичке карактеристике дијалекта, веровања и предања локалног становништа, народна ношња, традиционални модуси привређивања и ратовања и сл.). Уколико се покаже да је током XIX века етнографичност израженије присутна у српским путописима који извештавају о националном простору и култури, а има индиција да је управо тако, онда је ово стање ствари објашњиво следећим факторима.

${ }^{21}$ Иако то на први поглед изгледа чудно, поступци својствени панегиричком стилу („идеални пејзаж”, „топос неизрецивости”, „надмашивање”) прилично су чест део реторичког репертоара путописног жанра. Узрок томе може се потражити и у чињеници да су се још у позној антици појавили „прописи за похвалу градова” утемељени у панегиричким стилским формулама (Курцијус 1996: 262-263). 
Прво, „процес аутоидентификације српске нације, који је средином 19. века захватио све значајније сегменте јавног живота", па тако и науку и књижевност (Вукићевић 2007: 118), наметнуо је и путописној прози сасвим специфичне захтеве, што је утицало како на успостављање априрорне вредносне хијерархије унутар датог жанровског оквира, тако и на конституцију самих путописних састава. Према мишљењу Слободанке Пековић, тип путничких списа који доминира часописним страницама оног доба представљају текстови „о народу и крајевима који се данас не сматрају иностранством, а поготово не удаљеним, непознатим или нарочито занимљивим пределима", за шта основни разлог треба препознати у нарочитом задатку који је био испостављен пред ондашњу српску путописну прозу - „упознати свој народ”22 (в. Пековић 2001: 15-20). Сличне претензије могу се ишчитати и са страница Матавуљевих путописа: на пример, иако је студија Бока и Бокељи писана као „путни вођ извањцима”, у те „извањце” треба убројати пре свега „источне Србе”, чијем је разумевању овај текст био и језички прилагођен (в. Матавуљ 2008: 284). Све ово водило је ка томе да сазнајне вредности и функције написаног буду приоритетна брига путописацаิ кад год би извештавали о домаћем, националном простору, а то је несумњиво утицало и на степен етнографичности њихових радова.

Осим тога, заступљености овог дискурса допринела је и трајна, мање-више експлицитна полемика наших лите-

22 у питању је заправо тенденција која превазилази очекивања везана за одређени жанр. На пример, доминација „домаћег” путописа успостављена је и у часопису Вила током 60-их година XIX века, а данас се сматра да је читава уређивачка политика Стојана Новаковића била усклађена с националним програмом кнез Михаилове владе, тј. са прокламованом тежњом за „познавањем Србије и народа у њој" (Поповић 1999: 325-326). 
рата са страним путописцима и етнографима, која је била поведена зарад кориговања „погрешних” и злонамерних представа о српском народу. Индикативна је у том погледу и Матавуљева опаска о странцима који су му претходили у описивању Боке:

Овде не спомињем туђинце, који су у било ком правцу о Боци писали: само ћу казати да је тај крајичак наше отаџбине, по свој прилици, туђинству боље познат него ма који други. Одиста је и неверно приказан, особито од Немаца и после буна 1869. и 1881. То се не може оправдати, али се може разумети, јер је покретач томе народна мржња и политички рачун. (2008: 291)

У ствари, овде је на делу феномен који су заговорници постколонијалне критике именовали као „аутоетнографију” или „аутоетнографски израз". Иако је реч о појави која се изворно везује за колонијални контекст, тј. за „случајеве када колонизовани субјекти настоје да представе себе тако што ангажују термине самог колонизатора" (в. Прат 1992: 7-9), несумњиво је да је и за балкански простор, па и за српску књижевност, сасвим редовна појава „аутоегнографских текстова”, којима локални писци настоје да „етнографски” одговоре или макар да успоставе дијалог са културно доминантнијим репрезентацијама.

Тако смо се нешто заобилазним путем приближили проблему који је тренутно у жижи како историчара етнологије тако и методолога ове научне области. Реч је о одређеним (идеолошким) подразумевањима који употреба етнодескрипција обично активира. Како се етнологија обликовала као научни дискурс о ваневропским социокултурним заједницама, које се налазе на нижем ступњу цивилизацијског развоја, ${ }^{23}$ ова хуманистичка наука је била

${ }^{23}$ Довољно је само подсетити на нека одређења етнологије/ етнографије, којих смо се само успут дотакли у овом раду: „пос- 
област бројних значајних открића, али и место генезе разних дискриминаторних, хегемонијских, па и расијалистичких схватања. Уопште, употребити етнографски дискурс при опису одређене популације попримило је нарочите вредносне и идеолошке импликације. Занимљиво би било видети да ли контекст српске књижевности, ако се занемаре поменути аутоетнографски написи, и са̂м дозвољава стандардне идеолошке конотације које се тичу односа између етнографа и етнографисаног.

у Матавуљевом случају за ту врсту провере могу послужити три путописна текста са супротним географским

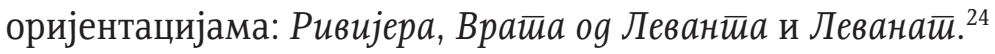
Удео етнографског дискурса у Матавуљевом извештају с туристичког обиласка Француске Ривијере није знатан у односу на присуство информативних коментара друкчије садржине. Чини се, заправо, да историографски коментар који се тиче политичке, војне, државне и културне прошлости овог региона доминира у овом путопису. Осим прошлости, Матавуљеву пажњу нарочито привлаче разноврсни појавни облици туризма, као специфичне културе путовања која свој пуни процват доживљава управо на том

матрање дивљих народа”, „проучавање архаичних култура”, „истраживање егзотичних друштава". Приметно је да је кретање кроз простор у етнологији (нарочито у еволуционистичким доктринама) било поистовећивано са „путовањем у прошлост” (в. Рид-Данахеј 2013: 410). Тек је у етнологији XX века учињен методолошки напор да се теренским радом и ангажовањем „учесника-посматрача" оповргну разноврсне парадигме о „примитивним” и „цивилизованим" народима.

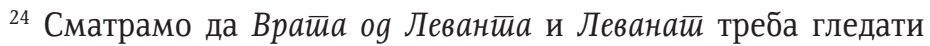

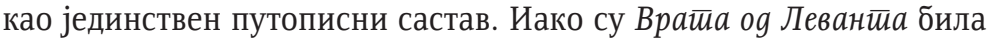
првобитно замишљена као самостална и завршена целина, аутор је неколико седмица касније дописао наставак. Овакво наше схватање потврђују одређени паратекстуални сингали и уводне реченице Леванйа. 
географском простору. Аутор је, не без карактеристичног иронијског отклона, заокупљен бројним аспектима демократизације путништва (бедекери и туристички водичи, организован смештај и превоз, програмиран избор путничих дестинација, индустрија доколице и разоноде), процесом који путничком искуству нужно одузима квалитет непатворености, па се отуда и селекција искуствене грађе овде у великој мери подудара с оним што слови за туристичку атракцију. У тако конципираном путопису, који извештава о таквом географском и културном простору, места за манифестовање традиционалне културе готово и да нема.

Путнички извештаји с Крфа овог аутора, иако настали у оквиру исте путничке парадигме, имају битно другачија својства. Путописни поступак овде се своди на смењивање етнографског (и псеудоетнографског) дискурса с нарацијом о незнатним свакодневним догађајима и безначајним сусретима, а све то одговара ауторовом доживљају овог острва као „чудне збрке свачега и свега” (Матавуљ 2008: 377). У ствари, готово потпуна доминација етнодескрипцијаิ у оквиру информативног дискурса (етнопсихолошке карактеристике, типична физиономија становништва, народна ношња и говор, обичајни и верски живот, традицинална архитектура) може се протумачити и као својеврстан минус поступак у односу на обиље и разноврсност података којима се одликује Матавуљево казивање о Ривијери. ${ }^{25}$ На сличан закључак упућује и итеративно приповедање којим се завршава овај напис: „Остадосмо на Крфу још три дана, разбиијајући чаму како смо могли, у разговорима са оцем Савом, у игрању домина, у решавању ребуса из илустрованих листова. Уз то, ја се

\footnotetext{
${ }^{25}$ Овакво интертекстуално повезивање, тј. читање крфских путописа на подлози путничког извештаја са Ривијере, сугерише са̂м аутор, назвавши Крф иронично „грчком Ницом”.
} 
чешће састајах са Јеврејином полиглотом, са летописцем берберином, или одлажах да посматрам поклонике чудотворца Спиридона, хранитеља властеоског дома Папа-Вулгариса." (2008: 396) Када је реч о крфским туристичким атракцијама, посебну пажњу Матавуљ посвећује дворцу Ахилеон, разглашеном тамошњем летњиковцу нетом страдале аустријске царице Елизабете. Нарочито су занимљива два детаља која запажа аутор приликом обиласка ове знамените грађевине: 1) испражњен и огољен дворски ентеријер, ${ }^{26}$ и 2) усамљени споменик Хајнриху Хајнеу, којем малобројни грчки туристи не знају ни име да изговоре.Етнографски дискурс постаје, тако, једини прикладан облик писања о месту на којем нема шта да се види или, можда, о месту које нема ко да види.

\section{ЛИТЕРАТУРА}

Матавуљ 1954: С. Матавуљ, Драме, ӣуйойиси, разни сйиси. Сабрана дела, књ. VII, ред. Г. Добрашиновић - Д. Живковић, Београд: Просвета.

Матавуљ 2007: С. Матавуљ, Прийовейке III, Сабрана дела Симе Матавуља, књ. 4, ур. др Г. Добрашиновић, Београд - Загреб: Завод за уџбенике - Српско културно друштво „Просвјета".

Матавуљ 2008: С. Матавуљ, Мемоарски и ӣуйойисни сӣиси. Сабрана дела Симе Матавуља, књ. 5, ред. др Г. Добрашиновић, Београд - Загреб: Завод за уџбенике - Српско културно друштво „Просвјета”.

${ }^{26}$ „У тој соби не беше ни једнога комада покућанства. Иза ње је царичино одељење, такође празно. Сиђосмо у доњи бој, намењен цару, такође празан. Најпосле спустисмо се у приземни спрат, где су: велика дворница, црквица у византијском слогу, трпезарија у слогу талијанске ренесансе и помпејанска клет за пушаче, све без покућанства, које је пренето у Беч." (2008: 395) 
Матавуљ 2009: С. Матавуљ, Прейиска. Сабрана дела Симе Матавуља, књ. 7, ред. др Г. Добрашиновић, Београд - Загреб: Завод за уџбенике - Српско културно друштво „Просвјета".

Борм 2000: J. Borm, „In Betweeners? - On the Travel Book and Ethnographies", Studies in Travel Writing, 4/1, 78-105.

Борм 2013: J. Borm, „Određivanje puta: o putu, putničkoj književnosti i terminologiji", prev. A. Kostadinović, Niš: Philologia Mediana, V/5, 607-621.

Влаховић 1986: П. Влаховић, „Нушићев допринос етнологији и фолклористици", у: Б. Ђ. Нушић, Косово: ойис земље и нароgа, Београд: Просвета, 299-308.

Вукићевић 2007: Д. Вукићевић, „Етнолошки код”, у: Д. Иванић - Д. Вукићевић, Ка йоетииนи срӣскоі реализма, Београд: Завод за уџбенике, 117-173.

Деретић 2007: Ј. Деретић, Исйорија срйске књиневносиии, Београд: SezamBook.

Дуда 2005: D. Duda, „Ostavljeno veslo na galiji nacije: književni modernizam i kultura putovanja", Beograd: Reč, 73/19, 97117.

Добрашиновић 2007: Г. Добрашиновић, „Објашњења”, у: С. Матавуљ, Прийовеикке III. Сабрана дела Симе Матавуља, књ. 4, ред. др Голуб Добрашиновић, Београд - Загреб: Завод за уџбенике - Српско културно друштво „Просвјета", 453-473.

Ђурчинов 2001: М. Ђурчинов, „О Нушићевом путопису Крај обала Охрияской језера", у:Сл. Пековић (ред.), Кюиі̄a о йyйойису, Београд: Институт за књижевност и уметност, 443-449.

Живковић 1954: Д. Ж[ивковић], „Напомене уз путописе и разне списе", у: С. Матавуљ, Драме, иууйойиси, разни сйиси. Сабрана дела, књ. VII, ред. Голуб Добрашиновић - Драгиша Живковић, Београд: Просвета, стр. 593-597.

Живковић 1994: Д. Живковић, „Хиперболички стилски комплекс у српској прози XVIII и XIX века", Евройски оквири срйске књиневносиич, књ. II, Београд: Просвета, 214-227. 
Иванић 1996: Д. Иванић, Срйски реализам, Нови Сад: Матица српска.

Кашанин 2004: М. Кашанин, „Ускок (Симо Матавуљ)”, Cygбине и љуgи: оіллеgи о срйским йисиима. Изабрана дела Милана Кашанина, књ. 5, Београд: Завод за уџбенике и наставна средства, 127-151.

Кембел 1988: M. В. Campbell, The Witness and the Other World. Exotic European Travel Writing, 400-1600, Ithaca - New York:Cornell University Press.

Клифорд 1988: J. Clifford, The Predicament of Culture. Twentieth-Century Ethnography, Literary and Art, Cambridge - Massachusetts - London: Harvard University Press.

Кораћ 1982: Ст. Кораћ, Књижевно дјело Симе Майавуља, Београд: Српска књижевна задруга.

Костадиновић 2016а: А. Костадиновић, „Аксиолошки статус путописа: између сублитерарног и паранаучног феномена", Koper: Trends and Tendencies in Modern Philology, Nr. 1, 17-33.

Костадиновић 2016б: А. Костадиновић, „Појам 'породичних сличности' и његова примена у генологији", у: Б. Димитријевић (ред.), Наука и савремени универзитети V (Савремена наука о језику и книневносии), Ниш: Филозофски факултет Универзитета у Нишу, 73-86.

Курцијус 1996: Е. Р. Курцијус, Евройска книневносии и лаичински среgюи век, прев. Ј. Бабић, Београд: Српска књижевна задруга.

Максимовић 2007: Г. Максимовић, „Путописна Бока Которска Лазара Томановића и Симе Матавуља", Искусивво и gоживљај. Срйске књижевне сйуgије 19. вијека, Београд: Филип Вишњић, 135-148.

Максимовић 2010: Г. Максимовић, „Путописно приповиједање: Симо Матавуљ као путописац", Комеgиографски Орфеј и gруі̄u оїлеgu, Београд: КИЗ Алтера, 77-107.

Нишкановић 2001: М. Нишкановић, „Путописно у етнолошким истраживањима", у: Сл. Пековић (ред.), Књиīa o üy- 
йойucy, Београд: Институт за књижевност и уметност, 235-240.

Пековић 2001: Сл. Пековић, „Путопис - условљеност жанра", у: у: Сл. Пековић (ред.), Књиі̄a о йуйойису, Београд: Институт за књижевност и уметност, 11-26.

Поарије 1999: Ž. Poarije, Istorija etnologije, prev. A. Mimica, Beograd: Plato.

Поповић 1999: П. Поповић, „Један стари књижевни лист ('Вила', 1865-1868)", Нова књижевности II. Og Бранка gо

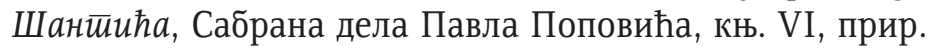
П. Палавестра, Београд: Завод за уџбенике и наставна средства, 319-333.

Прат 1986: M. L. Pratt, „Field workin Common Places”, in: J. Clifford - G. E. Marcus (eds.), Writing Culture: The Poetics and Politics of Ethnography, Berkley - Los Angeles: University of California Press, 27-50.

Прат 1992: M. L. Pratt, Imperial Eyes: Studies in Travel Writing and Transculturation, New York: Routledge.

Рид-Данахеј 2013: D. Reed-Danahay, „Ethnography”, in: J. Speake(ed.), Literature of Travel and Exploration: an Encyclopedia, vol. one A-E, New York: Routledge, 410-411.

Рубијес 2000: J.-P. Rubiés, „Travel writing as a genre: facts, fictions and the invention of a scientific discourse in early modern Europe", The International Journal of Travel and Travel Writing, 5/33, 5-33.

Рубијес 2002: J.-P. Rubies, „Travel writing and ethnography”, in: P. Hulme - T. Youngs(eds.), The Cambridge Companion to Travel Writing, Cambridge: Cambridge University Press, 242-260.

Скерлић 1997: Ј. Скерлић, Истиорија нове срйске књижевнос$\bar{u} u$, прир. Ј. Пејчић, Београд: Завод за уџбенике и наставна средстава.

Томпсон 2011: C. Thompson, Travel Writing, New York: Routledge. 


\title{
Aleksandar Kostadinović \\ ETHNOGRAPHIC ASPECTS OF SIMO MATAVULJ'S TRAVELOGUES
}

\begin{abstract}
Summary
The paper discusses modes of ethnographic discourse presence in Simo Matavulj's travelogues, conditioned by the complex combination of various factors: genre, iterological, political... Besides the "ethnographic impulse", i.e. spontaneous ethnographism which is customary for the genre of travelogue in general, particular attention will be paid to liminal cases: 1) reduction of ethnographic discourse in the travel story, and 2) its development into systematic ethnographic description.

Key words: ethnographic discourse, travelogue, narrative ethnography, travel story, ethnographic impulse
\end{abstract}

